\title{
Synthesis of magnesium-zinc-yttrium master alloy
}

\author{
S. A. Savchenkov ${ }^{\dagger, 1}$, V.Y. Bazhin ${ }^{1}$, V. N. Brichkin ${ }^{1}$, V. G. Povarov ${ }^{1}$, \\ V.L. Ugolkov' ${ }^{2}$ D. R. Kasymova ${ }^{1}$ \\ †savchenkov.tlc@bk.ru \\ ${ }^{1}$ Saint Petersburg Mining University, 2 21st Line, St. Petersburg, 199106, Russia \\ ${ }^{2}$ I. V. Grebenshchikov Institute of Silicate Chemistry RAS, 2 Adm. Makarov Quay, St. Petersburg, 199155, Russia

\begin{abstract}
The research investigates the process of synthesis of magnesium master alloy with zinc and yttrium. Based on the analysis of state diagrams and requirements for fluxes for smelting of magnesium alloys, the composition of the saline mixture was chosen. X-ray phase analysis of the molten salt mixture showed that during the melting process, yttrium fluoride partially interacted with sodium and potassium chlorides, forming complex salts: $\mathrm{Na}_{1.5} \mathrm{Y}_{2.5} \mathrm{~F}_{9}, \mathrm{NaYF}_{4}, \mathrm{Na}_{5} \mathrm{Y}_{9} \mathrm{~F}_{32}$, and $\mathrm{KY}_{7} \mathrm{~F}_{22}$, which are the source for yttrium recovery. Differential thermal analysis (DTA) determined the temperature ranges and values of thermal effects of melting and crystallization of a mixture of the $\mathrm{KCl}-\mathrm{NaCl}-\mathrm{CaCl}_{2}-\mathrm{YF}_{3}$ salt in the recovery of yttrium compounds by a magnesium-zinc alloy. It was determined that interaction within the system begins at a temperature equal to the initial melting point of zinc, and occurs in the range from $415^{\circ} \mathrm{C}$ to $672^{\circ} \mathrm{C}$. As a result of series of experimental meltings, the basic laws of the synthesis of magnesium-zinc-yttrium master alloys from the selected technological salt mixture, as well as the main factors of the metallothermic process, affecting the degree of yttrium reduction were revealed. The metallographic study of the alloys obtained showed that the samples consisted of solid solutions of $\mathrm{Mg}_{x} \mathrm{Zn}_{y}$ and intermetallic compounds of $\mathrm{Mg}_{x} \mathrm{Y}_{y} \mathrm{Zn}_{z}$, which were located along the boundaries of dendritic cells. The proposed method of recovery of yttrium fluoride from the chloride melt allows extracting up to $97.2 \%$ of yttrium.
\end{abstract}

Keywords: magnesium master alloys, magnesium-yttrium, master alloys synthesis.

УДК: 669.721 .5

\section{Синтез лигатуры магний-цинк-иттрий}

\author{
Савченков С. А. ${ }^{\dagger}, 1$, Бажин В. Ю. ${ }^{1}$, Бричкин В. Н. ${ }^{1}$, Поваров В. Г. ${ }^{1}$, \\ Уголков В. Л. ${ }^{2}$, Касымова Д. Р. ${ }^{1}$ \\ ${ }^{1}$ Санкт-Петербургский горный университет, Васильевский остров, 21 линия, 2, С.-Петербург, 199106, Россия \\ ${ }^{2}$ Институт химии силикатов им. И. В. Гребенщикова РАН, наб. Макарова, 2, С.-Петербург, 199034, Россия
}

\begin{abstract}
Статья посвящена изучению процесса синтеза магниевых лигатур с цинком и иттрием. На основе анализа диаграмм состояния и требований, предъявляемых к флюсам для плавки магниевых сплавов, выбран состав солевой смеси. Рентгенофазовый анализ проплавленной солевой смеси показал, что при плавлении трифторид иттрия частично взаимодействует с хлоридами натрия и калия, образуя комплексные соли: $\mathrm{Na}_{1.5} \mathrm{Y}_{2.5} \mathrm{~F}_{9}, \mathrm{NaYF}_{4}, \mathrm{Na}_{5} \mathrm{Y}_{9} \mathrm{~F}_{32}$ и $\mathrm{KY}_{7} \mathrm{~F}_{22}$ из которых и происходит восстановление иттрия. Дифференциально-термическим анализом (ДТА) определены интервалы температур и величины тепловых эффектов плавления и кристаллизации солевой смеси $\mathrm{KCl}-\mathrm{NaCl}-\mathrm{CaCl}_{2}-\mathrm{YF}_{3}$ при восстановлении соединений иттрия магниево-цинковым сплавом. Установлено, что взаимодействие в системе начинается при температуре, соответствующей температуре начала плавления цинка, и происходит в диапазоне от $415^{\circ} \mathrm{C}$ до $672^{\circ} \mathrm{C}$. В результате проведения серии экспериментальных плавок выявлены основные закономерности синтеза лигатур магний-цинк-иттрий из подобранной технологической солевой смеси, выявлены основные факторы металлотермического процесса, влияющие на степень восстановления иттрия. Проведенное металлографическое исследование полученных лигатур показало, что образцы состоят из твердого раствора $\mathrm{Mg}_{x} \mathrm{Zn}_{y}$ и интерметаллических соединений $\mathrm{Mg}_{x} \mathrm{Y}_{y}$, которые располагаются по границам дендритных ячеек. Предложенный способ восстановления фторида иттрия из хлоридного расплава позволяет извлекать иттрий в процентном соотношении до $97.2 \%$.
\end{abstract}

Ключевые слова: магниевые лигатуры, магний-иттрий, синтез лигатур. 


\section{Introduction}

Yttrium and zinc are the most commonly used alloying elements in the production of heat-resistant magnesium alloys of various compositions: Mg-Y-Sm-Zn-Zr, Mg-Sn-Zn-Y, Mg-Gd-Y-Zn-Mn, Mg-Gd-Y-Zn, Mg-Y-Zn-Zr, etc. [1-7]. The addition of zinc reduces the grain size and increases the strength of magnesium, and $\mathrm{Mg}-\mathrm{Zn}$ alloys are strengthened during subsequent heat treatment. Yttrium increases the creep resistance of magnesium alloys at elevated temperatures up to $250^{\circ} \mathrm{C}$ [8-12].

It is known that magnesium alloys are produced using two- and three-component master alloys, whose production methods are being actively studied all over the world [13-19]. The need to use master alloys is due to the low rate of dissolution of pure high-heat components in liquid magnesium, as well as an increase in the assimilation degree of easily oxidizing alloying elements. Taking into consideration the nature of the distribution of the component in the master alloy materials and its dissolution rate in the magnesium melt, it is possible to obtain the specified content of the alloying component in the alloy by adding a certain amount of the master alloy to the charge. Rare earth metals and, in particular, yttrium, are introduced into magnesium alloys by the means of two-component master alloys, which are produced in two main ways: by fusion of pure components, and by reduction of alloying elements from compounds.

However, it should be noted that the method for obtaining two-component master alloys by fusion is characterized by high temperatures of the process, and, therefore, high irreversible losses of yttrium, and the method for obtaining two-component master alloys by recovery of yttrium from its compounds is characterized by low recovery rates of yttrium $(65-80 \%)[20-21]$. Therefore, in some cases it is more feasible to produce three-component master alloys [22-23]. Due to this, it is important to substantiate and develop scientific and methodological approaches to the synthesis of three-component master alloys in the metallothermic recovery of yttrium compounds, considering the selection of rational technological parameters.

\section{Equipment, materials and methods}

An elemental analysis of samples of salt mixtures and the produced master alloys was performed using a sequential wave X-ray fluorescence spectrometer XRF-1800 (Shimadzu). The phases were identified using an XRD-7000 $\mathrm{X}$-ray powder diffractometer (Shimadzu) $\left(\mathrm{Cu}_{\mathrm{Ka}}\right.$-radiation, angle range $2 \theta=10-80^{\circ}$, shooting speed $2^{\circ} / \mathrm{min}$ ).

A comprehensive thermal analysis was performed using CD STA 429 (NETZSCH) in alundum crucibles with covers in a stream of argon (using a crucible holder of the "TG+DTA» type with a thermocouple of the "S" (Pt-PtRh10) type. At the same time, the curves of mass change - TG (in \%) of the initial sample and the curves of DTA change (in $\mu \mathrm{v} / \mathrm{mg}$ ) were obtained. Before and after heating, the samples were photographed using an MPB-2 microscope at $24 \times$ magnification directly in crucibles.

A metallographic study of the samples of the obtained master alloys was performed using an electron microscope
VEGA (TESCAN, Czech Republic) with an energy dispersive spectrometer INCAx-act (Oxford, England). Preparation of samples for metallographic studies included cutting of templates using a cutting machine with a diamond wheel, as well as subsequent grinding and polishing. Prior to polishing, the templates were fixed in a mandrel and filled with self-hardening acrylic plastic. Polishing was done using sandpaper with a reduction of the dispersion of abrasive particles. After polishing with sandpaper, polishing with finegrained corundum paste was conducted.

A shaft electro-furnace (Russia, Mining University) with silicon carbide heaters was used in the laboratory. To increase the rate of the complete exchange reaction of molten salts with magnesium and zinc, all melts were agitated with a steel impeller.

Investigation and selection of technological parameters of melting processes were carried out on the basis of the conducted research experiments and analysis of scientific and technical information in the field of basic technical parameters of the production of magnesium alloys. All experiments were conducted with magnesium grade Mg90 and granular zinc (AR), qualification of initial salts: $\mathrm{KCl}, \mathrm{NaCl}, \mathrm{CaCl}_{2}$, (R.), $\mathrm{YF}_{3}$ (AR).

Melting tests were carried out according to the following methodology. First, a technological salt mixture consisting of chlorides and yttrium trifluoride was prepared in advance. Then the salts were rigorously agitated, after which the salt mixture together with magnesium and zinc was placed in a crucible, which was installed in an oven, kept at a temperature of 600 to $800^{\circ} \mathrm{C}$ for $10-30$ minutes with continuous stirring at a speed of up to $350 \mathrm{rpm}$. At the end of the reduction reaction, the melt was settled for a specified time during which the separation of the reaction products took place: the upper layer consisted of the melt of salts; the lower level was the Mg-Zn-Y master alloy. Further, the surface part of the salts melt was poured into a slag ingot mold together with slag, and the resulting master alloy was poured into ingots.

\section{Results and discussion}

The fluxes used for the production of magnesium-REM master alloys must meet the following basic requirements: the components of fluxes must have no interaction with either magnesium or REM; the salt mixture must have a low melting point, which is below the level of the magnesium melting point; the salt mixture must have a low viscosity; the produced master alloys must be easily separated from the salt mixture. Based on exploratory research and preliminary smelting, a salt mixture of the composition $35 \mathrm{KCl}-35 \mathrm{NaCl}-30 \mathrm{CaCl}_{2}$ was selected. The selected mixture meets all the aforementioned requirements [24].

To identify common patterns of stages of the synthesis of the $\mathrm{Mg}-\mathrm{Zn}-\mathrm{Y}$ master alloys from a chloride-fluoride melt consisting of $\mathrm{KCl}-\mathrm{NaCl}-\mathrm{CaCl}_{2}-\mathrm{YF}_{3}$, an X-ray analysis of molten salt mix was conducted, which showed that yttrium trifluoride partially interacted with sodium and potassium chlorides during the melting process, with the formation of complex salts of yttrium: $\mathrm{Na}_{1.5} \mathrm{Y}_{2.5} \mathrm{~F}_{9}, \mathrm{NaYF}_{4}, \mathrm{Na}_{5} \mathrm{Y}_{9} \mathrm{~F}_{32}$ and $\mathrm{KY}_{7} \mathrm{~F}_{22}$.

At the next stage, thermal studies of the yttrium reduction process by a magnesium-zinc alloy were carried out. 
Fig. 1 illustrates the thermograms obtained with the first (green curves) and second (purple curves) sequential heating of ingot magnesium, granular zinc and a mixture of $35 \mathrm{KCl}-35 \mathrm{NaCl}-30 \mathrm{CaCl}_{2}$ and $\mathrm{YF}_{3}$ salts in a dynamic flow of argon at a heating rate of $10^{\circ} \mathrm{C} / \mathrm{min}$ to a temperature of $780^{\circ} \mathrm{C}$, and a speed of $1^{\circ} \mathrm{C} / \mathrm{min}$ to a temperature of $800^{\circ} \mathrm{C}$, followed by cooling the melt at a speed of $10^{\circ} \mathrm{C} / \mathrm{min}$. The weight of the sample was $310 \mathrm{mg}$.

During the first melting of the charge, the beginning of zinc melting at $415.4^{\circ} \mathrm{C}$ is observed, which is accompanied by an endothermic effect with a maximum at $435.5^{\circ} \mathrm{C}$, after which zinc actively begins to interact with magnesium, which is characterized by an exothermic peak with a minimum at $446.6^{\circ} \mathrm{C}$ and completes the interaction at $473.8^{\circ} \mathrm{C}$. It is possible that during this interaction yttrium can be reduced by a magnesium-zinc melt. At a temperature of $473.8^{\circ} \mathrm{C}$, one can observe the onset of another exothermic effect with a minimum at $514.5^{\circ} \mathrm{C}$, which apparently indicates the continuation of the process of recovery of yttrium fluoride by a magnesium-zinc melt. Endothermic effects with maxima at $596.4^{\circ} \mathrm{C}$ and $672.4^{\circ} \mathrm{C}$ correspond to the melting of the salt mixture.

During the second heating, the thermogram indicates the endothermic effects of melting of a magnesium-zinc alloy with a maximum at $350.9^{\circ} \mathrm{C}$ and a salt mixture with a maximum at $533.9^{\circ} \mathrm{C}$, and it is also possible to detect an endothermic melting peak with a maximum at $603.8^{\circ} \mathrm{C}$, which may correspond to the melting of the formed $\mathrm{Mg}_{x} \mathrm{Y} \mathrm{Zn}_{z}$ compound. During the second melting exothermic effects are not observed.

Fig. 2 illustrates the thermograms obtained while cooling the sample to $200^{\circ} \mathrm{C}$ at a rate of $10^{\circ} \mathrm{C}$ per minute. During the first (blue curves) and the second (burgundy curves) cooling, two thermal effects of crystallization with minima at $506-508.4^{\circ} \mathrm{C}$ and $624.8-625.4^{\circ} \mathrm{C}$ are clearly observed on the thermogram. In addition, it is possible to detect the exothermic crystallization peak with a minimum at $588.3-590.0^{\circ} \mathrm{C}$, which may correspond to the crystallization of the resulting $\mathrm{Mg}_{x} \mathrm{Y}_{y} \mathrm{Zn}_{z}$ triple compound.
The final stage includes an experimental study of the synthesis of the Mg-Zn-Y master alloy. It has been found that the process of yttrium fluoride reduction is accompanied by the formation of a homogeneous magnesium-zinc-yttrium master alloy, with a significant effect on the degree of yttrium transition being provided by the process temperature, which should be at least $680^{\circ} \mathrm{C}$. Under these conditions, the minimum time for the yttrium recovery reaction (15 minutes) is needed, and favorable conditions for the operation of agitation devices are provided. With an increase in temperature up to $800^{\circ} \mathrm{C}$, the yttrium yield does not change significantly, but the irreversible losses of magnesium and zinc increase greatly.

It has also been found in the experiments that the addition of zinc to the feed increases the yield of yttrium in the master alloy. This is due to the formation of compounds of the $\mathrm{Mg}_{x} \mathrm{Y} \mathrm{Zn}_{z}$ type in the alloy, which is consistent with the thermodynamic description of the $\mathrm{Mg}-\mathrm{Zn}-\mathrm{Y}$ system presented in [25]. As a result of experimental studies of the process manufacturing of $\mathrm{Mg}-\mathrm{Zn}$-Y master alloys, samples of the master alloy with yttrium content from 10 to $25 \mathrm{wt}$ \% have been obtained, while the extraction of yttrium from fluoridechloride melts has reached 97.2\%. X-ray phase analysis of the produced master alloys has shown the presence of the threecomponent phase of $\mathrm{Mg}_{3} \mathrm{YZn}_{6}$ and two-component phase of $\mathrm{Zn}_{3} \mathrm{Mg}_{7}$ [26].

Microstructural analysis of the obtained samples (Fig. 3) has shown that yttrium-containing master alloys had a solid solution structure with a uniform distribution of $\mathrm{Mg}_{x} \mathrm{Y} \mathrm{Zn}_{z}$ intermetallics within the magnesium-zinc matrix. The number of intermetallic compounds in the master alloy increased with increasing yttrium content.

Electron microprobe analysis (Fig. 4) of the structure parts shows that in the magnesium-zinc matrix (dark areas) the magnesium content is $92.68 \mathrm{wt} . \%$, and the zinc content is 7.32 wt.\%. Eutectic intermetallic compounds (light sectors), contain about 59 wt.\% zinc, 17 wt.\% magnesium and 24 wt.\% yttrium.

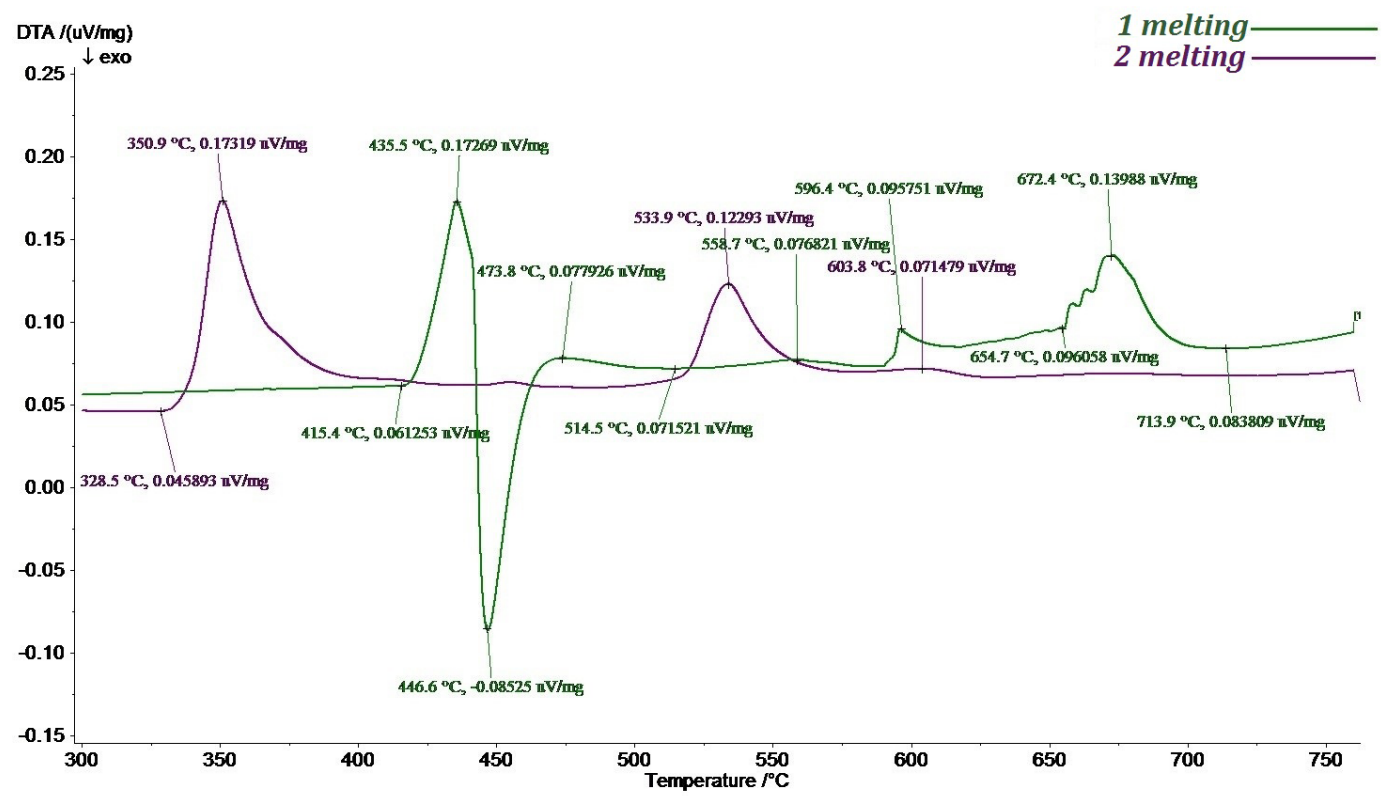

Fig. 1. (Color online) Thermograms of the first and second meltings of the studied sample of $\mathrm{Mg}-\mathrm{Zn}-\mathrm{KCl}-\mathrm{NaCl}-\mathrm{CaCl}_{2}-\mathrm{YF}_{3}$ when heated to $800^{\circ} \mathrm{C}$. 


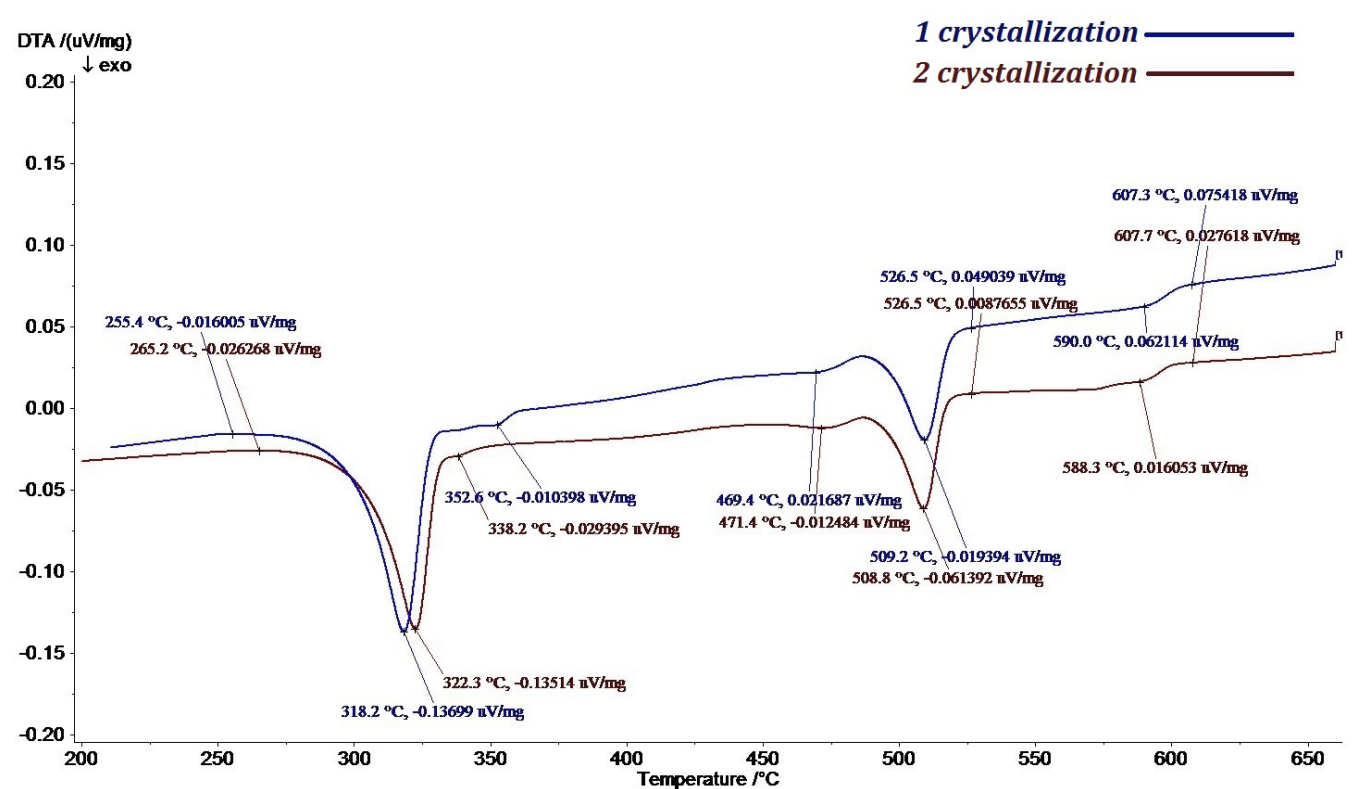

Fig. 2. (Color online) Thermograms of the first and second crystallization of the studied sample of $\mathrm{Mg}-\mathrm{Zn}-\mathrm{KCl}-\mathrm{NaCl}_{-}-\mathrm{CaCl}_{2}-\mathrm{YF}_{3}$ when cooled to $200^{\circ} \mathrm{C}$.

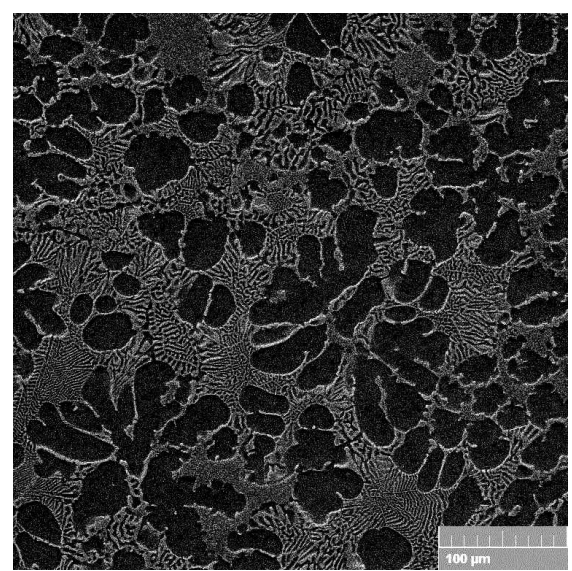

a

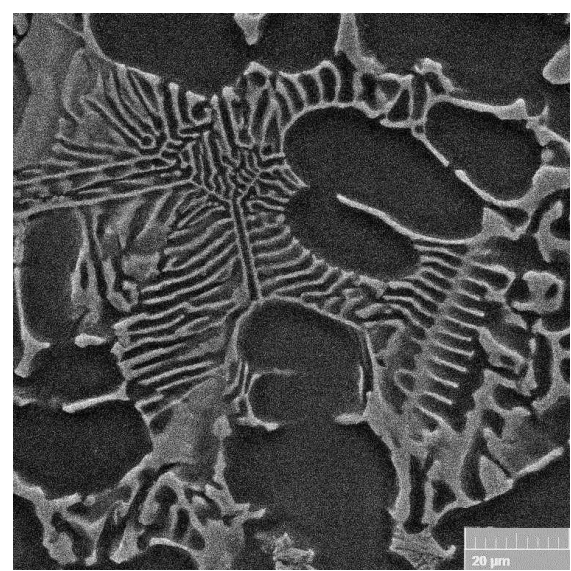

b

Fig. 3. Microstructure of the $35 \mathrm{Mg}-45 \mathrm{Zn}-20 \mathrm{Y}$ master alloy: $\times 500$ (a), $\times 2000$ (b).
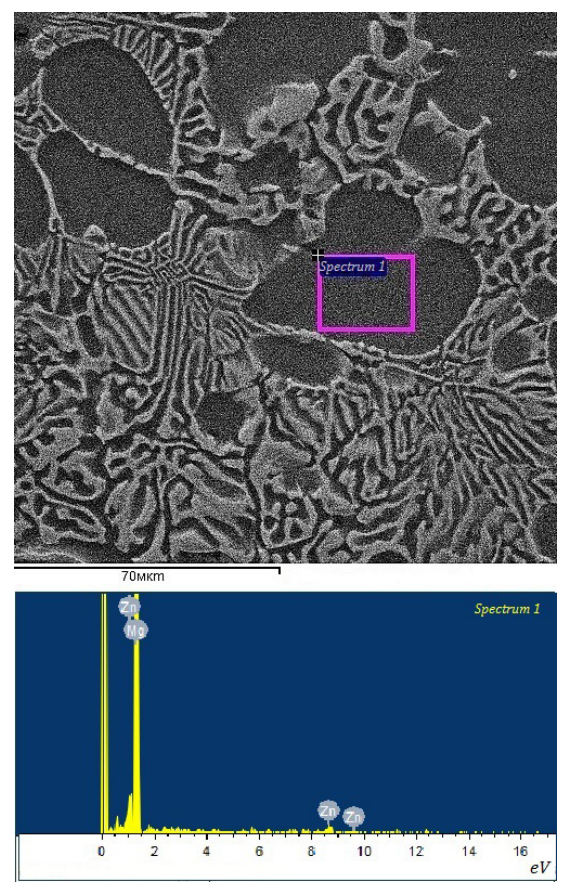
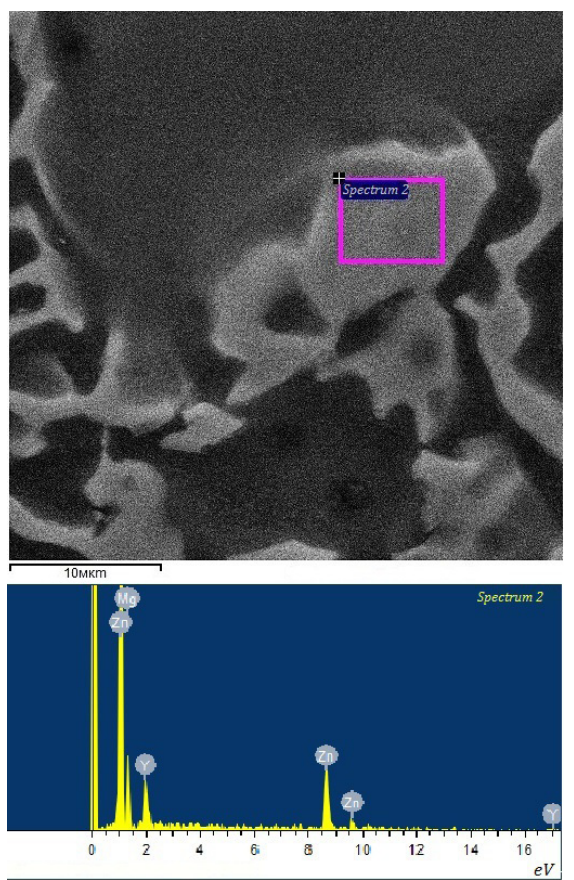

Fig. 4. Microstructure of $35 \mathrm{Mg}-45 \mathrm{Zn}-20 \mathrm{Y}$ master alloy, $\times 2000$. 


\section{Conclusions}

Thus, as a result of the tests, it was found that interaction of yttrium trifluoride with the molten process salt mixture containing potassium chlorides, sodium and calcium, results in the formation of complex salts, namely: $\mathrm{Na}_{1.5} \mathrm{Y}_{2.5} \mathrm{~F}_{9}, \mathrm{NaYF}_{4}$, $\mathrm{Na}_{5} \mathrm{Y}_{9} \mathrm{~F}_{32}$ and $\mathrm{KY}_{7} \mathrm{~F}_{22}$.

Using differential thermal analysis (DTA), the temperature ranges of the thermal effects of melting and crystallization of the components of the salt mixture $\mathrm{KCl}-\mathrm{NaCl}-\mathrm{CaCl}_{2}-\mathrm{YF}_{3}$ were determined during the recovery of yttrium compounds with the magnesium-zinc melt.

It was found that the temperature at the stage of producing a magnesium master alloy should be at least $680^{\circ} \mathrm{C}$, while the minimum time ( 15 minutes) was spent on the yttrium reduction reactions from yttrium complex compounds.

It was found that the addition of zinc to the charge helped to increase the yield of yttrium into the master alloy to $97.2 \%$ since when zinc was added during magnesiumthermal reduction of yttrium, a significant amount of heat was released.

A metallographic study of the obtained master alloys showed that the samples consisted of a magnesium-zinc matrix $\mathrm{Mg}_{x} \mathrm{Zn}_{y}$ and a eutectic structure with intermetallic compounds $\mathrm{Mg}_{x} \mathrm{Y}_{y} \mathrm{Zn}_{z}$.

Acknowledgements. The research was carried out with the financial support of the Ministry of education and science of the Russian Federation (project registration number 11.4098.2017/PM from 01.01.2017).

\section{References}

1. S. Lyu, G. Li, T. Hu, R. Zheng, W. Xiao, C.Ma. Materials Letters. 217, 79 (2018). Crossref

2. Y. Chen, Y. Wang, J. Gao. J. Alloys and Comp. 740, 727 (2018). Crossref

3. R. Zhang, J. Wang, S. Huang, S. Liu, F. Pan. Journal of Magnesium and Alloys. 5 (3), 355 (2017). Crossref

4. X. Yu, B. Jiang, J. He, B. Liu, Z. Jiang, F. Pan. J. Alloys and Comp. 687, 252 (2016). Crossref

5. K. Liu, J. Zhang, D. Tang, L.L. Rokhlin, F.M. Elkin, J. Meng. Materials Chemistry and Physics. 117 (1), 107 (2009). Crossref

6. K. Liu, L.L. Rokhlin, F.M. Elkin, D. Tang, J. Meng. Materials Science and Engineering. 527 (3), 828 (2010). $\underline{\text { Crossref }}$

7. K. Liu, J. Zhang, H. Lu, D. Tang, L. L. Rokhlin, F. M. Elkin, J. Meng. Materials \& Design. 31 (1), 210 (2010). Crossref

8. Y. Chen, Y. Wang, J. Gao. J. Alloys and Comp. 740, 727 (2018). Crossref
9. S. H. Lu, D. Wu, R. S. Chen, E. Han. Materials Science and Engineering. 735, 173 (2018). Crossref

10. B. Q. Shi, Y.Q. Cheng, X. L. Shang, H. Yan, R.S. Chen, W. Ke. Materials Science and Engineering: A. 743, 558 (2019). Crossref

11. Y. Sun, R. Wang, C. Peng, Y. Feng. Materials Science and Engineering: A. 733, 429 (2018). $\underline{\text { Crossref }}$

12. L. Liu, F. Pan, X. Chen, Y. Huang, B. Song, H. Yang, N. Hort. Vacuum. 155, 445 (2018). Crossref

13. V. V. Kaminsky, S.A. Petrovich, V.A. Lipin. Journal of Mining Institute. 233, 512 (2018). (in Russian) [В.В. Каминский, С.А. Петрович, В.А. Липин. Записки Горного института. 233, 512 (2018).] Crossref

14. B. Nagasivamuni, G. Wang, D. H. StJohn, M. S. Dargusch. Journal of Crystal Growth. 512, 20 (2019). Crossref

15. V.Y. Bazhin, E. M. Gutema, S. A. Savchenkov. Metallurgist. 60 (11-12), 1267 (2017). Crossref

16. W. Guobing, P. Xiaodong, L. Junchen, X. Weidong, W. Quny. Rare Metal Materials and Engineering. 42 (10), 2009 (2013). Crossref

17. P. Xiaodong, L. Junchen, X. Sunyun, W. Guobin. Rare Metal Materials and Engineering. 42 (12), 2421 (2013). Crossref

18. C. Wang, M. Sun, F. Zheng, L. Peng, W. Ding. Journal of Magnesium and Alloys. 2, 239 (2014). $\underline{\text { Crossref }}$

19. M. Sun, X. Hu, L. Peng, P. Fu, W. Ding, Y. Peng. Journal of Materials Processing Technology. 218, 57 (2015). Crossref

20. N. V. Baryshnikov, L.P. Skripaleva, V.D. Savin, G. G. Morozov, A.S. Derevyanko. Trudy Giredmeta. 74, 20 (1974). (in Russian) [H.В. Барышников, Л.П. Скрипалева, В.Д. Савин, Г.Г. Морозов, А. С. Деревянко. Труды Гиредмета. 74, 20 (1974).]

21. S. A. Savchenkov, V.Yu. Bazhin. TU Bergakademie Freiberg Scientific Reports on Resource Issues. 1. 315 (2016).

22. Y. Li, X. Huang, Q. Fu, G. Liu, H. Li, Y.Liu. Procedia Engineering. 27, 1808 (2012). $\underline{\text { Crossref }}$

23. E. Mosisa, V. Yu. Bazhin, S. A. Savchenkov. Research Journal of Applied Sciences. 11 (5), 188 (2016). Crossref

24. S.A. Savchenkov, V.Yu. Bazhin, V.N. Brichkin, Ya.I. Kosov, V.L. Ugolkov. Metallurg. 4, 71 (2019). (in Russian) [С. А. Савченков, В. Ю. Бажин, В. Н. Бричкин, Я.И. Косов, В. Л. Уголков. Металлург. 4, 71 (2019).]

25. Z.Z. Arthur, D. Pelton. J. Alloys and Comp. 652, 426 (2015). Crossref

26. S. A. Savchenkov, V.L. Ugolkov. Proceedings of Irkutsk State Technical University. 1 (23), 187 (2019). (in Russian) [С.А. Савченков, В.Л. Уголков. Вестник Иркутского государственного технического университета. 1 (23), 187 (2019).] Crossref 